\title{
Improvement of Postharvest Keeping Quality of Bell Pepper (Capsicum annum L.) Fruits Treated with Different Chemicals following Cold Storage
}

\author{
K.S. Thakur, Kiran Jyoti, Satish Kumar* and Sunakshi Gautum \\ Department of Food Science and Technology, Dr. Y S Parmar University of Horticulture and \\ Forestry, Nauni, Solan, H P-173230, India \\ *Corresponding author
}

\section{A B S T R A C T}

The present study was conducted during 2013-14 in Postharvest Physiology Laboratory, Department of Food Science and Technology, UHF, Nauni. Freshly harvested bell peppers were procured from the local growers, properly packed in suitable containers and were promptly transported to the laboratory for the layout of the experiments. Only fresh and healthy fruits were selected, washed and air dried

\begin{tabular}{|l|}
\hline Ke y w or d s \\
1-MCP \\
fumigation, \\
Salicylic acid, \\
Calcium chloride \\
dip, $\mathrm{H}_{2} \mathrm{O}_{2}$ dip, \\
Postharvest \\
quality. \\
\hline Article Info \\
\hline Accepted: \\
23 June 2017 \\
Available Online: \\
10 July 2017 \\
\hline \hline
\end{tabular}
before they were subjected to different postharvest treatment, including 1-MCP fumigation $(500,700,1000 \mathrm{ppb}$ for 24 hours), salicylic acid dip $(1000,2000$ and $3000 \mathrm{ppm}$ for $5 \mathrm{~min}$.), calcium chloride dip $(0.5,1$ and $1.5 \%$ for $5 \mathrm{~min})$ and $\mathrm{H}_{2} \mathrm{O}_{2}$ dip $(5,10$ and $15 \mathrm{mM} 30 \mathrm{~min})$ respectively. $1-\mathrm{MCP}$ treatment proved to be the most effective treatment in retaining storage quality as the treated fruits exhibited lowest physiological loss in weight besides showing lower changes in total soluble solids, reducing and total sugars and total phenol content in fruits after 28 days storage. The treatment was also effective in reducing the respiration rate, thereby reducing the overall ripening process and prolonging storage life of fruits. $\mathrm{H}_{2} \mathrm{O}_{2}$ dip for 30 minutes@15mM was found to be most effective in reducing spoilage. Salicylic acid dip treatments for 5 minutes $(1000 \mathrm{ppm})$ exhibited lower decrease in dry matter content and retained maximum capsaicin content in fruits whereas, $\mathrm{CaCl}_{2}$ treatment @ 1.5 per cent retained maximum titratable acidity, ascorbic acid and was also an effective in minimizing deterioration in fruit quality and extending shelf life. It was concluded that among the postharvest treatments 1-MCP fumigation@1000 ppb proved to be most effective treatment in maintaining fruit quality and minimizing deterioration during 28 days storage at $10 \pm 2{ }^{\circ} \mathrm{C}$ and it was followed by salicylic acid dip for 5 minutes @ 1000 ppm, 5 minute dip in 1.5 per cent calcium chloride and $\mathrm{H}_{2} \mathrm{O}_{2}$ dip for 30 minutes @ $15 \mathrm{mM}$, respectively.

\section{Introduction}

Bell pepper (Capsicum annum L.) commonly known as Capsicum, Sweet pepper or Shimla Mirch is a Solanaceous vegetable and is popular for its delicious taste, pleasant flavor and nutritional quality. Bell pepper is a native of Mexico with secondary centre of origin in Gautemala. In India, it was introduced by the
Britishers in the $19^{\text {th }}$ century in Shimla Hills (Singh et al., 1993) and is cultivated over an area of about 29 thousand hectare with an annual production of 159,000 metric tonnes (NHB, 2014). This crop is extensively cultivated in Himachal Pradesh, Uttarakhand, Jammu and Kashmir, Andhra Pradesh and 
Nilgiri Hills during summer and as an autumn crop in Karnataka, Maharashtra, Tamil Naidu, Bihar, West Bengal and Madhya Pradesh. In Himachal it is grown during summer and rainy seasons as an off-season crop. Bell pepper fruits are generally blocky, square, thick fleshed, three to four lobed, nonpungent and are eaten raw, used as a vegetable or widely used in stuffings, bakings, pizza and preparation of soups for imparting flavour. Bell pepper has high nutritional value, and is rich source of vitamin C (150-180 mg/100g), $\beta$-carotene and folic acid, significantly helpful in curing cancer (Mateljan, 2007) and many other degenerative diseases.

Bell pepper is a climacteric fruit and is especially prone to water loss and consequently shriveling due to their large surface to weight ratio. They are also susceptible to fungal infections caused by Botrytis cinerea and Alternaria alternate which may lead to postharvest and economic losses to the growers if not controlled. Further, problem is aggravated during peak production periods when farmers are tempt to store their produce for short periods to avoid distress sales but due to non-availability of proper storage facilities in production areas and lack of knowledge regarding postharvest handling that could facilitate the storage for such short durations, there are huge postharvest losses of the produce. Such losses can be overcome by the use of appropriate technology with a potential to retain the storage quality of the freshly harvested produce.

1-Methylcyclopropene (1-MCP) is an antagonist of ethylene action that binds to the ethylene receptor molecule after treatment of fruits and delays ripening and the associated changes that are generally accelerated by ethylene (Sisler and Serek, 1997). Similarly, preharvest or pre-storage application of salicylic acid is a useful tool for controlling postharvest decay thereby extending storage life (Wang and Shaohua, 2008). The application of plant nutrients like calcium has also been reported to maintain cell integrity and firmness of fruits during storage (Ochie et al., 1993). Similarly, the use of $\mathrm{H}_{2} \mathrm{O}_{2}$ for disinfecting vegetables is reported to reduce microbial populations on fresh products and extend the shelf life without leaving significant residues or causing loss of quality (Sapres et al., 2001).

\section{Materials and Methods}

Bell peppers were procured from the local growers and only healthy disease free fruits were harvested from the field. They were properly packed in suitable containers and were promptly transported to the Postharvest Physiology Laboratory, Department of Food Science and Technology, UHF, Nauni, for conducting the studies. In this experiment, 1methylcyclopropene (1-MCP) was applied as a fumigation treatment by placing the fruits in a closed tent with a calculated amount of chemical dissolved in water and a battery operated fan for 24 hours for circulation of the gas around the fruits. Salicylic acid, calcium chloride and hydrogen peroxide were applied as postharvest dip treatments after preparing aqueous solutions of required strengths as per details mentioned below:

After the application of postharvest treatments fruits were air dried in shade and packed in corrugated fibre board (CFB) cartons for storage at $10 \pm 2^{\circ} \mathrm{C}$. Observations regarding physico-chemical changes of fruits were recorded at an interval of 7 days during the storage period of 28 days. Total soluble solid contents were recorded with the help of an Erma hand refractometer. Ascorbic acid content was determined as per standard AOAC method (Ranganna, 1986) using 2, 6dichlorophenol indophenol dye. 


\begin{tabular}{|l|l|l|}
\hline Treatment No. & Chemicals & Concentration \\
\hline$T_{1}$ & 1-MCP fumigation for 24 hours & $500 \mathrm{ppb}$ \\
\hline$T_{2}$ & 1-MCP fumigation for 24 hours & $750 \mathrm{ppb}$ \\
\hline$T_{3}$ & 1-MCP fumigation for 24 hours & $1000 \mathrm{ppb}$ \\
\hline$T_{4}$ & Salicylic acid dip for 5 minutes & $1000 \mathrm{ppm}$ \\
\hline$T_{5}$ & Salicylic acid dip for 5 minutes & $2000 \mathrm{ppm}$ \\
\hline$T_{6}$ & Salicylic acid dip for 5 minutes & $3000 \mathrm{ppm}$ \\
\hline$T_{7}$ & Calcium chloride dip for 5 minutes & $0.5 \%$ \\
\hline$T_{8}$ & Calcium chloride dip for 5 minutes & $1.0 \%$ \\
\hline$T_{9}$ & Calcium chloride dip for 5 minutes & $1.5 \%$ \\
\hline$T_{10}$ & $\mathrm{H}_{2} \mathrm{O}_{2}$ dip for 30 minutes & $5 \mathrm{mM}$ \\
\hline$T_{11}$ & $\mathrm{H}_{2} \mathrm{O}_{2}$ dip for 30 minutes & $10 \mathrm{mM}$ \\
\hline$T_{12}$ & $\mathrm{H}_{2} \mathrm{O}_{2}$ dip for 30 minutes & $15 \mathrm{mM}$ \\
\hline$T_{13}$ & Control & \\
\hline & & \\
\hline
\end{tabular}

Sugars were estimated by Lane and Eynon method (Lane and Eynon, 1923). Total phenols were extracted in 80 per cent ethanol and estimated on the basis of their reaction with an oxidizing agent phosphomolybdate in Folin- Ciocalteau reagent under alkaline conditions (Bray and Thorpe, 1954). Capsaicin content was determined by the colorimetric method (Sadasivam and Manickam, 1978). Respiration was measured with the help of Gas data analyzer (GFM series 30-1/2/3, GAS Data Ltd. Conventry UK) and was expressed as $\mathrm{ml} \mathrm{CO}_{2} / \mathrm{kg} / \mathrm{hr}$.

\section{Results and Discussion}

Fumigation with 1-methylcyclopropene (1MCP) proved to be the most effective treatment with minimum PLW whereas, other treatments including salicylic acid, calcium chloride and hydrogen peroxide were also quite effective (Table 1). There was a progressive and continuous increase in PLW of fruits with an increase in storage period up to 28 days irrespective of the treatments applied. The highest PLW was observed in control (3.53\%), whereas, lowest PLW (2.94\%) was observed in fruits treated with $1000 \mathrm{ppb} 1-\mathrm{MCP}$ which was in close interaction with 1-MCPfumigation for 24 hours $(750 \mathrm{ppb})$, salicyclic acid for $5 \mathrm{~min}$
(3000 ppm), $\mathrm{CaCl}_{2}$ dip for 5 minutes $(1.5 \%)$ and $\mathrm{H}_{2} \mathrm{O}_{2}$ for 30 minutes $(10 \mathrm{mM})$, respectively (Table 1). Physiological loss in weight of fruits during storage is primarily due to losses of stored metabolites as they are utilized during respiration and losses of water from the fruit surface contribute to PLW which is mainly due to transpiration although some of this water may also be lost by respiration and evaporation (Wilkinson, 1965). The results of present finding are in line with those reported on carrot (Issac and Maalekuu, 2013), 'Honey Dew' melon (Saftner et al., 2003), mango (Akhtar et al., 2010) and 'Canino' apricot (Farag et al., 2012), as a result of calcium application.

Spoilage symptoms in control fruits and at lower concentration of some treatments appeared as soon as $14^{\text {th }}$ day, whereas in fruits treated with such 1-MCP symptoms were observed on the $21^{\text {st }}$ day of storage (Table 1). Minimum spoilage $(2.77 \%)$ was recorded with the application of hydrogen peroxide @ $10 \mathrm{mM}\left(\mathrm{T}_{12}\right)$ and it was closely followed by $1-$ MCP (1000 ppb) fumigation for 24 hours, 1MCP fumigation for 24 hours (750 ppb), 1MCP fumigation for 24 hours (500 ppb), $\mathrm{H}_{2} \mathrm{O}_{2}$ dip for 30 minutes $(10 \mathrm{mM})$, and salicylic acid dip for 5 minutes (3000 ppm), respectively. On the other hand, maximum 
spoilage $(17.13 \%)$ was recorded in control fruits and which was significantly highest in comparison to all other treatments (Table 1). Afek et al., (1999) also found $\mathrm{H}_{2} \mathrm{O}_{2}$ to be effective in reducing spoilage and extending storage life of fruit during overseas shipments.

The lowest dry matter content (6.24\%) was observed in the fruits samples treated with salicylic acid @ 1000 ppm $\left(\mathrm{T}_{4}\right)$ and it was followed statistically at par with salicylic acid 2000 ppm and 3000 ppm for 5 minutes and $\mathrm{CaCl}_{2}(0.5 \%)$ dip for 5 minutes, respectively compared to control which had highest dry matter content of 7.12 per cent (Table 2). Higher dry matter content in control fruits could possibly be due to higher rates of moisture loss from such fruits, as they also exhibited the highest physiological loss in weight during storage. Yeganah et al., (2013) observed that table grapes treated with salicylic acid (2 and $4 \mathrm{mM}$ ) generally had lower dry matter content than the control fruits.

The titratable acidity of fruits declined with advancement in storage periods under all treatments (Table 2). The decline was slowest in fruits treated with calcium chloride 1.5 per cent which consequently retained significantly highest acidity $(0.30 \%)$ followed by calcium chloride @ 1.0 per cent (0.26\%), $\mathrm{H}_{2} \mathrm{O}_{2} @ 15 \mathrm{mM}(0.25 \%)$, salicylic acid @ 3000 ppm (0.24\%) and @ 1000 ppm $(0.17 \%)$, respectively. Other treatments were also effective in retaining titratable acidity of fruits during storage the untreated fruits however, had the lowest mean acidity values $(0.15 \%)$ which observed a sharp decline during storage. The decrease in acidity of the samples in the present study was due to the conversion of acids into sugars however the slower rate of decline of acidity in fruits treated with calcium, salicylic acid and $\mathrm{H}_{2} \mathrm{O}_{2}$ was due to reduced sensitivity of the fruits to ethylene and reduced fruit respiration. In the present study calcium chloride @ 1.5 per cent retained highest mean titratable acidity and similar results have been reported previously in papaya (Marpudi et al., 2011), peach (Tareen et al., 2012), tomato (Anthon et al., 2011), pear (Mahajan et al., 2010), apple (Schaik et al., 1992), etc.

It was observed that there was a gradual decline in ascorbic acid content of fruits with advancement in storage in all treatments. The maximum mean ascorbic acid content of $91.06 \mathrm{mg} / 100 \mathrm{~g}$ was recorded in fruits treated with calcium chloride@1.5 per cent which was followed by the treatments salicylic acid @ 3000 ppm (91.00 mg/100 g), calcium chloride@ 1.0 per cent $(90.97 \mathrm{mg} / 100 \mathrm{~g})$, salicylic acid 2000 ppm (90.91 mg/100 g)and $\mathrm{H}_{2} \mathrm{O}_{2}$ dip @15 mM (90.89mg/100 g), respectively, and minimum $(90.17 \mathrm{mg}$ per 100 g) in control sample (Table 2) at the end of the storage. The loss in ascorbic acid content during storage might be due to its degradation during metabolic processes or through enzymatic oxidation of L-ascorbic acid to dehydro ascorbic acid (Mapson, 1970), as well as utilization by developing microorganisms (Tandon and Tandon, 1974; Taneja et al., 1983; Ruoyi et al., 2005) also reported that peach fruits treated with 0.5 per cent $\mathrm{CaCl}_{2}$ retained highest ascorbic acid after 50 days of cold storage.

Total soluble solids (TSS), total sugars and reducing sugars contents of fruit in generally increases initially, reaching a peak value and then decreases during storage irrespective of the treatments during the storage. Results revealed that the fruits treated with 1-MCP fumigation@ 1000 ppb retained highest mean TSS (6.89 ${ }^{\circ}$ B) followed by 1-MCP @ 750 ppb $\left(6.84^{\circ} \mathrm{B}\right), 1-\mathrm{MCP}$ fumigation @ $500 \mathrm{ppb}$ $\left(6.78^{\circ} \mathrm{B}\right)$, and $\mathrm{CaCl}_{2} @ 1.5$ per cent $\left(6.67^{\circ} \mathrm{B}\right)$, respectively (Table 3$)$. On the other hand minimum TSS content $\left(6.17^{\circ} \mathrm{B}\right)$ was recorded 
in control fruits which were significantly lower than other treatments. Slower reduction in TSS and sugar contents in fruits treated with 1- MCP was due restricted respiration of the fruits and have earlier been reported in peppers (Bayoumi, 2008), capsicum (Park et al., 2001), sweet pepper (Behra et al., 2004), plum (Salvador et al., 2003) and peach (Cuquel et al., 2006; Chen et al., 2005) which lend further credence to the present results. Following a similar trend the reducing sugar, content decreased under all treatments with a progressive increase in storage duration up to the 28 day storage period (Table 3 ).

The maximum and significantly higher mean reducing sugar content $(2.75 \%)$ was recorded in response to 1-MCP @ $1000 \mathrm{ppb}$ and was followed by the treatments 1-MCP @ $750 \mathrm{ppb}$ (2.68\%), $500 \mathrm{ppb}(2.60 \%)$ and $\mathrm{H}_{2} \mathrm{O}_{2}(15 \mathrm{mM})$ dip for 30 minutes (2.57\%), respectively. Other treatments were also effective in retaining higher reducing sugar contents during storage compared to the untreated fruits which recorded the lowest mean value $(2.35 \%)$. The maximum mean total sugars content $(4.62 \%)$ was also recorded for 1-MCP $1000 \mathrm{ppb}$ followed by 1-MCP $750 \mathrm{ppb}$ (4.58\%) and $500 \mathrm{ppb}(4.55 \%)$ (Table 3). On the other hand the minimum total sugar content $(3.78 \%)$ was recorded in control samples.

Fruit TSS, reducing sugar and total sugar changes followed a typical respiratory curve behavior and the samples treated with 1-MCP showed a gradual increase in fruit TSS, reducing sugar and total sugars reaching the maximum value on $21^{\text {st }}$ day and then declined, which in control fruits was obtained as soon as on $14^{\text {th }}$ day of storage following a sharp decline thereafter. Similar observations have been reported previously in peppers (Bayoumi, 2008), capsicum (Park et al., 2001), sweet pepper (Behra et al., 2004), plum (Salvador et al., 2003) and peach
(Cuquel et al., 2006; Chen et al., 2005) which lend further credence to the present results.

Capsaicin content of fruits also declined with the advancement in storage period irrespective of the treatment applied. The maximum mean capsaicin content $(0.69 \%)$ was recorded in fruit samples treated with salicylic acid @ 3000 ppm followed by $\mathrm{H}_{2} \mathrm{O}_{2}$ dip @ 15 mM (0.67\%) (Table 4). The control fruits exhibited the lowest mean capsaicin content $(0.53 \%)$ was significantly lower than other treatments. Topuz and Ozdemir (2004) reported changes in capsaicinoids of paprika during ten months of storage. Under ambient storage, the level of each capsaicinoid in paprika was significantly decreased with storage. Generally, all capsaicinoid components decreased almost 30 per cent within ten months of storage and maximum decrease was recorded in dihydrocapsaicin.

There was gradual continuous decline in phenolic content of bell pepper fruits during storage. However, different treatments were effective in slowing down the decrease in total phenols to varying extents (Table 4). The maximum mean phenolic contents of 45.25 $\mathrm{mg} / 100 \mathrm{~g}$ was found in fruits treated with 1MCP @ 1000 ppb and it was followed by $\mathrm{H}_{2} \mathrm{O}_{2}$ dip @ $15 \mathrm{mM}$ (45.13 mg/100 g), $\mathrm{CaCl}_{2}$ @ 1.5 per cent $(45.09 \mathrm{mg} / 100 \mathrm{~g}), 1-\mathrm{MCP}$ fumigation@ $0750 \mathrm{ppb}(43.69 \mathrm{mg} / 100 \mathrm{~g})$ and $\mathrm{CaCl}_{2} @ 1.0$ per cent $(43.53 \mathrm{mg} / 100 \mathrm{~g})$, respectively (Table 4). The control fruits exhibited the lowest mean total phenol (37.75 $\mathrm{mg} / 100 \mathrm{~g}$ ). This decrease is probably due to the oxidation by polyphenol oxidase (PPO) (Yamaguchi et al., 2003). Similar results have been reported in 'Nangau' pear (Cheng et al., 2012) and strawberry fruits (Jiang et al., 2001; Tian et al., 2000). Moreover, Robardset. al. (1999) found that phenolic compounds have a significant role in oxidation processes as antioxidants and as substrates in browning reactions. 
Table.1 Effect of postharvest treatments on changes in physiological loss in weight (\%) and spoilage (\%) of bell pepper during refrigerated storage at $10 \pm 2{ }^{\circ} \mathrm{C}$ and $90-95 \% \mathrm{RH}$

\begin{tabular}{|c|c|c|c|c|c|c|c|c|c|c|}
\hline & \multicolumn{5}{|c|}{ PLW (\%) } & \multicolumn{5}{|c|}{ Spoilage $(\%)$} \\
\hline & \multicolumn{5}{|c|}{ Storage interval in days } & \multicolumn{5}{|c|}{ Storage interval in days } \\
\hline $\mathbf{T}_{1}$ & $3.05(1.74)^{*}$ & $3.19(1.78)$ & $3.22(1.80)$ & $3.63(1.91)$ & $3.27(1.80)$ & $\begin{array}{c}0.00 \\
(1.00)^{*}\end{array}$ & $0.00(1.00)$ & $5.12(2.47)$ & $12.23(3.64)$ & $4.34(2.03)$ \\
\hline $\mathbf{T}_{2}$ & $2.50(1.58)$ & $2.80(1.67)$ & $3.18(1.78)$ & $3.56(1.89)$ & $3.01(1.73)$ & $0.00(1.00)$ & $0.00(1.00)$ & $4.41(2.33)$ & $11.76(3.57)$ & $4.04(1.97)$ \\
\hline $\mathbf{T}_{3}$ & $2.41(1.55)$ & $2.76(1.66)$ & $3.10(1.76)$ & $3.49(1.87)$ & $2.94(1.71)$ & $0.00(1.00)$ & $0.00(1.00)$ & $3.05(2.01)$ & $10.42(3.38)$ & $3.37(1.85)$ \\
\hline $\mathbf{T}_{4}$ & $2.78(1.67)$ & $3.10(1.76)$ & $3.44(1.85)$ & $3.80(1.95)$ & $3.28(1.81)$ & $0.00(1.00)$ & $3.50(2.12)$ & $8.85(3.14)$ & $15.93(4.11)$ & $7.07(2.59)$ \\
\hline $\mathbf{T}_{6}$ & $2.60(1.61)$ & $2.95(1.72)$ & $3.30(1.82)$ & $3.66(1.91)$ & $3.13(1.77)$ & $0.00(1.00)$ & $0.00(1.00)$ & $5.50(2.55)$ & $12.45(3.67)$ & $4.49(2.05)$ \\
\hline $\mathbf{T}_{7}$ & $2.88(1.70)$ & $3.18(1.78)$ & $3.35(1.83)$ & $3.76(1.94)$ & $3.29(1.81)$ & $0.00(1.00)$ & $2.41(1.85)$ & $7.98(3.00)$ & $14.78(3.97)$ & $6.29(2.45)$ \\
\hline $\mathbf{T}_{8}$ & $2.83(1.68)$ & $3.10(1.76)$ & $3.28(1.81)$ & $3.68(1.92)$ & $3.22(1.79)$ & $0.00(1.00)$ & $1.65(1.63)$ & $6.54(2.75)$ & $13.65(3.83)$ & $5.46(2.30)$ \\
\hline $\mathbf{T}_{9}$ & $2.77(1.67)$ & $3.02(1.74)$ & $3.20(1.79)$ & $3.61(1.90)$ & $3.15(1.77)$ & $0.00(1.00)$ & $1.10(1.45)$ & $6.14(2.67)$ & $13.10(3.75)$ & $5.09(2.22)$ \\
\hline$T_{10}$ & $2.94(1.71)$ & $3.23(1.80)$ & $3.39(1.84)$ & $3.69(1.92)$ & $3.31(1.82)$ & $0.00(1.00)$ & $0.56(1.25)$ & $5.83(2.61)$ & $12.82(3.72)$ & $4.80(2.14)$ \\
\hline$T_{11}$ & $2.88(1.70)$ & $3.18(1.78)$ & $3.32(1.82)$ & $3.62(1.90)$ & $3.25(1.80)$ & $0.00(1.00)$ & $0.00(1.70)$ & $3.12(2.03)$ & $10.54(3.40)$ & $3.42(2.03)$ \\
\hline$T_{12}$ & $2.82(1.68)$ & $3.10(1.76)$ & $3.28(1.81)$ & $3.57(1.89)$ & $3.19(1.78)$ & $0.00(1.00)$ & $0.00(1.68)$ & $2.97(1.99)$ & $8.12(3.02)$ & $2.77(1.92)$ \\
\hline Control & $2.98(1.73)$ & $3.38(1.84)$ & $3.74(1.93)$ & $4.02(2.00)$ & $3.53(1.88)$ & $0.00(1.00)$ & $10.10(3.33)$ & $21.674 .76)$ & $36.76(6.14)$ & $17.13(3.81)$ \\
\hline Mean & $2.78(1.66)$ & $3.08(1.75)$ & $3.22(1.82)$ & $3.68(1.92)$ & & $0.00(1.00)$ & $1.66(1.60)$ & $6.84(2.71)$ & $14.38(3.86)$ & \\
\hline \multicolumn{6}{|c|}{$\mathrm{CD}_{0.05}$} & \multicolumn{5}{|c|}{$\mathrm{CD}_{0.05}$} \\
\hline \multicolumn{2}{|c|}{ Treatments $(\mathrm{T}) \quad 0.01$} & \multirow{2}{*}{\multicolumn{4}{|c|}{006}} & \multicolumn{3}{|c|}{$\begin{array}{ll}\text { Treatments }(\mathrm{T}) & 0.09\end{array}$} & & \\
\hline \multicolumn{2}{|c|}{ StorageInterval(I) } & & & & & \multicolumn{3}{|c|}{ StorageInterval(I) $\quad 0.05$} & & \\
\hline TxI & & 0.02 & & & & TX I & & & & \\
\hline
\end{tabular}

*figures in the parenthesis are square root transformed values 
Table.2 Effect of postharvest treatments on changes in dry matter content (\%), titratable acidity (\% citric acid) and ascorbic acid content $(\mathrm{mg} / 100 \mathrm{~g})$ of bell pepper during refrigerated storage at $10 \pm 2^{\circ} \mathrm{C}$ and $90-95 \% \mathrm{RH}$

\begin{tabular}{ccccc} 
& & \multicolumn{3}{c}{ Dry matter content (\%) } \\
& $\mathbf{7}$ & $\mathbf{1 4}$ & $\mathbf{2 1}$ & $\mathbf{2 8}$ \\
$\mathbf{T}_{\mathbf{1}}$ & 5.90 & 6.30 & 7.53 & 7.50 \\
$\mathbf{T}_{\mathbf{2}}$ & 5.97 & 6.39 & 7.60 & 7.44 \\
$\mathbf{T}_{\mathbf{3}}$ & 6.04 & 6.47 & 7.70 & 7.53 \\
$\mathbf{T}_{\mathbf{4}}$ & 5.41 & 5.85 & 6.49 & 7.20 \\
$\mathbf{T}_{\mathbf{5}}$ & 5.50 & 5.88 & 6.52 & 7.22 \\
$\mathbf{T}_{\mathbf{6}}$ & 5.58 & 5.92 & 6.55 & 7.23 \\
$\mathbf{T}_{\mathbf{7}}$ & 5.66 & 5.93 & 6.52 & 7.22 \\
$\mathbf{T}_{\mathbf{8}}$ & 5.72 & 5.99 & 6.62 & 7.31 \\
$\mathbf{T}_{\mathbf{9}}$ & 5.79 & 6.07 & 6.70 & 7.40 \\
$\mathbf{T}_{\mathbf{1 0}}$ & 5.82 & 6.17 & 6.76 & 7.45 \\
$\mathbf{T}_{\mathbf{1 1}}$ & 5.85 & 6.19 & 6.79 & 7.48 \\
$\mathbf{T}_{\mathbf{1 2}}$ & 5.88 & 6.22 & 6.82 & 7.52 \\
$\mathbf{C o n t r o l}$ & 6.15 & 6.65 & 7.72 & 7.98 \\
$\mathbf{M e a n}$ & 5.79 & 6.16 & 6.95 & 7.42 \\
$\mathrm{CD}_{0.05}$ & & & & \\
Storage & $(\mathrm{S})$ & 0.03 & & \\
Treatment & $(\mathrm{T})$ & 0.02 & & \\
Interaction & $(\mathrm{T} \times \mathrm{I})$ & 0.07 & &
\end{tabular}

Titratableaciditycontent $(\%$ citric acid)

Storage interval in days

Mean $\quad 7 \quad$ Storage interval in days

6.81

6.85

6.94

6.24

6.28

6.32

6.33

6.41

6.49

6.55

6.58

6.61

7.12

\begin{tabular}{lccc}
\multicolumn{7}{c}{} & $\mathbf{1 4}$ & $\mathbf{2 1}$ & \\
0.23 & 0.19 & 0.16 & 0.14 \\
0.24 & 0.21 & 0.18 & 0.17 \\
0.29 & 0.24 & 0.20 & 0.20 \\
0.22 & 0.19 & 0.15 & 0.13 \\
0.25 & 0.23 & 0.19 & 0.15 \\
0.29 & 0.26 & 0.21 & 0.18 \\
0.27 & 0.25 & 0.22 & 0.19 \\
0.30 & 0.27 & 0.25 & 0.22 \\
0.35 & 0.31 & 0.29 & 0.25 \\
0.23 & 0.20 & 0.18 & 0.14 \\
0.27 & 0.23 & 0.21 & 0.18 \\
0.30 & 0.27 & 0.24 & 0.20 \\
0.19 & 0.17 & 0.14 & 0.12 \\
0.26 & 0.23 & 0.20 & 0.17 \\
CD $_{0.05}$ & & & \\
Storage & & $(\mathrm{S})$ & 0.01 \\
Treatment & $(\mathrm{T})$ & 0.02 \\
Interaction & $(\mathrm{T} \times \mathrm{I})$ & 0.04
\end{tabular}

Mean
0.18
0.20
0.23
0.17
0.21
0.24
0.23
0.26
0.30
0.19
0.22
0.25
0.15

Ascorbic acid content (mg/100g)

\begin{tabular}{|c|c|c|c|c|}
\hline \multicolumn{5}{|c|}{ Storage interval in days } \\
\hline 7 & 14 & 21 & 28 & Mean \\
\hline 95.21 & 92.87 & 88.62 & 85.57 & 90.57 \\
\hline 95.35 & 92.99 & 88.69 & 85.66 & 90.67 \\
\hline 95.59 & 93.13 & 88.78 & 85.72 & 90.80 \\
\hline 95.23 & 93.24 & 88.90 & 85.83 & 90.80 \\
\hline 95.40 & 93.40 & 88.95 & 85.89 & 90.91 \\
\hline 95.53 & 93.53 & 88.99 & 85.96 & 91.00 \\
\hline 95.65 & 93.23 & 88.87 & 85.77 & 90.88 \\
\hline 95.77 & 93.29 & 88.94 & 85.86 & 90.97 \\
\hline 95.87 & 93.38 & 89.03 & 85.94 & 91.06 \\
\hline 95.44 & 92.92 & 88.72 & 85.70 & 90.70 \\
\hline 95.64 & 92.99 & 88.79 & 85.75 & 90.79 \\
\hline 95.85 & 93.09 & 88.83 & 85.80 & 90.89 \\
\hline 95.05 & 92.17 & 88.16 & 85.31 & 90.17 \\
\hline 95.51 & 93.09 & 88.79 & 85.75 & \\
\hline \multicolumn{5}{|l|}{$\mathrm{CD}_{0.05}$} \\
\hline Storage & & \multicolumn{2}{|c|}{ (S) $\quad 0.03$} & \\
\hline \multicolumn{2}{|c|}{ Treatment } & \multicolumn{2}{|c|}{ (T) $\quad 0.07$} & \\
\hline Interacti & & $\mathrm{T} \times \mathrm{I})$ & & \\
\hline
\end{tabular}


Table.3 Effect of postharvest treatments on changes in TSS ( $\left.{ }^{\circ} \mathrm{B}\right)$, Reducing sugar $(\mathrm{mg} / 100 \mathrm{~g})$ and Total sugar (mg/100g) of bell pepper during refrigerated storage at $10 \pm 2^{\circ} \mathrm{C}$ and $90-95 \% \mathrm{RH}$

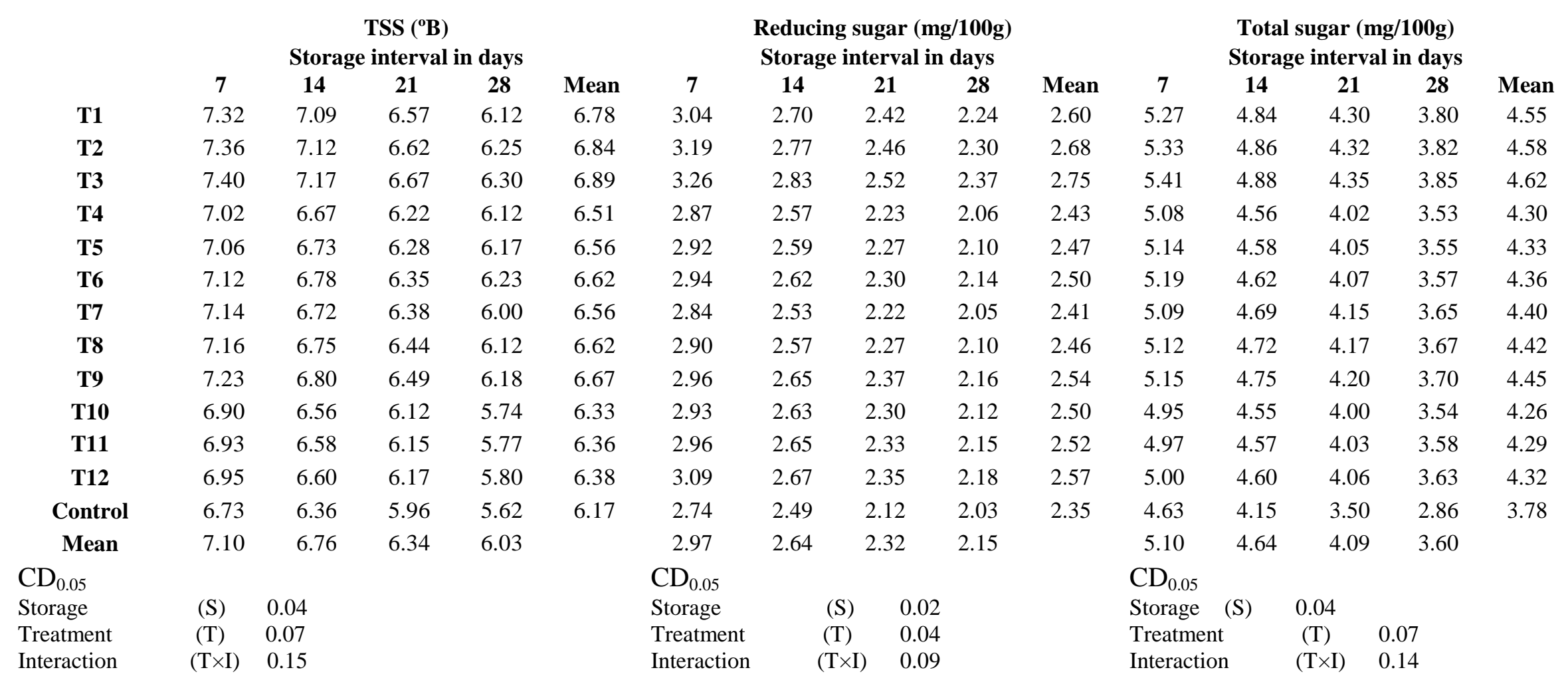


Table.4 Effect of postharvest treatments on changes in capsaicin content (\%), Total phenols (mg/100g) and respiration rate (ml $\mathrm{CO}_{2} / \mathrm{kg} / \mathrm{h}$ ) of bell pepper during refrigerated storage at $10 \pm 2^{\circ} \mathrm{C}$ and $90-95 \% \mathrm{RH}$

\section{Capsaicin content (\%) Storage interval in days}

$\begin{array}{ccc} & \mathbf{7} & \mathbf{1 4} \\ \mathbf{T 1} & 0.70 & 0.64 \\ \mathbf{T 2} & 0.73 & 0.66 \\ \mathbf{T 3} & 0.75 & 0.68 \\ \mathbf{T 4} & 0.72 & 0.66 \\ \mathbf{T 5} & 0.76 & 0.68 \\ \text { T6 } & 0.79 & 0.72 \\ \mathbf{T} 7 & 0.67 & 0.60 \\ \text { T8 } & 0.72 & 0.63 \\ \text { T9 } & 0.74 & 0.66 \\ \text { T10 } & 0.68 & 0.62 \\ \text { T11 } & 0.70 & 0.66 \\ \text { T12 } & 0.73 & 0.69 \\ \text { Control } & 0.60 & 0.56 \\ \text { Mean } & 0.71 & 0.65 \\ \text { CD } & & \\ \text { Storage } & (\mathrm{S}) & 0.01 \\ \text { Treatment } & (\mathrm{T}) & 0.02 \\ \text { Interaction } & (\mathrm{T} \times \mathrm{I}) & 0.04\end{array}$

Total phenols (mg/100g) Storage interval in days

7
45.42
47.26
49.48
42.48
44.30
46.54
45.50
47.34
49.58
46.42
48.26
50.48
42.33
46.57
$\mathrm{CD}_{0.05}$

Storage

Treatment

Interaction

\section{4}

\section{4}

42.26

45.49

47.36

39.32

41.52

43.58

42.28

44.56

46.40

43.24

45.48

47.32

40.44

43.79

$\begin{array}{cc}\mathbf{2 1} & \mathbf{2 8} \\ 39.68 & 36.58 \\ 42.23 & 39.76 \\ 43.62 & 40.55 \\ 36.86 & 33.34 \\ 38.72 & 36.72 \\ 41.26 & 38.82 \\ 39.72 & 36.66 \\ 42.36 & 39.87 \\ 43.74 & 40.65 \\ 39.90 & 36.23 \\ 41.56 & 37.80 \\ 42.80 & 39.90 \\ 36.36 & 31.87 \\ 40.68 & 37.60\end{array}$

$\begin{array}{cr}\text { (S) } & 0.02 \\ (\mathrm{~T}) & 0.04 \\ (\mathrm{~T} \times \mathrm{I}) & 0.09\end{array}$

\section{Respiration rate $(\mathrm{ml} \mathrm{CO} / \mathrm{kg} / \mathrm{h})$} Storage interval in days

Mean
40.99
43.69
45.25
38.00
40.32
42.55
41.04
43.53
45.09
41.45
43.28
45.13
37.75

$\begin{array}{ccccc}\mathbf{7} & \mathbf{1 4} & \mathbf{2 1} & \mathbf{2 8} & \begin{array}{c}\text { Mea } \\ \mathbf{n}\end{array} \\ 18.75 & 18.13 & 17.22 & 16.56 & 17.67 \\ 18.72 & 18.09 & 17.18 & 16.53 & 17.63 \\ 18.68 & 18.06 & 17.14 & 16.50 & 17.60 \\ 18.82 & 18.22 & 17.32 & 16.68 & 17.76 \\ 18.78 & 18.18 & 17.28 & 16.66 & 17.73 \\ 18.74 & 18.14 & 17.25 & 16.62 & 17.69 \\ 18.88 & 18.27 & 17.37 & 16.70 & 17.81 \\ 18.84 & 18.24 & 17.33 & 16.67 & 17.77 \\ 18.80 & 18.20 & 17.30 & 16.64 & 17.74 \\ 18.90 & 18.29 & 17.39 & 16.75 & 17.83 \\ 18.87 & 18.26 & 17.36 & 16.72 & 17.80 \\ 18.83 & 18.23 & 17.33 & 16.62 & 17.75 \\ 19.57 & 18.84 & 18.02 & 17.50 & 18.48 \\ 18.86 & 18.24 & 17.35 & 16.70 & \end{array}$

$\mathrm{CD}_{0.05}$

Storage

(S) 0.02

Treatment

(T) 0.04

Interaction

(T×I) 0.09 
Fig.1 Comparative effect of 1-MCP (1000ppb), salicylic acid (1000ppm), $\mathrm{CaCl} 2$ (1.5\%) and $\mathrm{H} 2 \mathrm{O} 2$ treatments on changes in sensory quality (color, texture, aroma and overall acceptability) of bell pepper on different sampling dates during refrigerated storage at $10 \pm 2^{\circ} \mathrm{C}$ and $90-95 \% \mathrm{RH}$
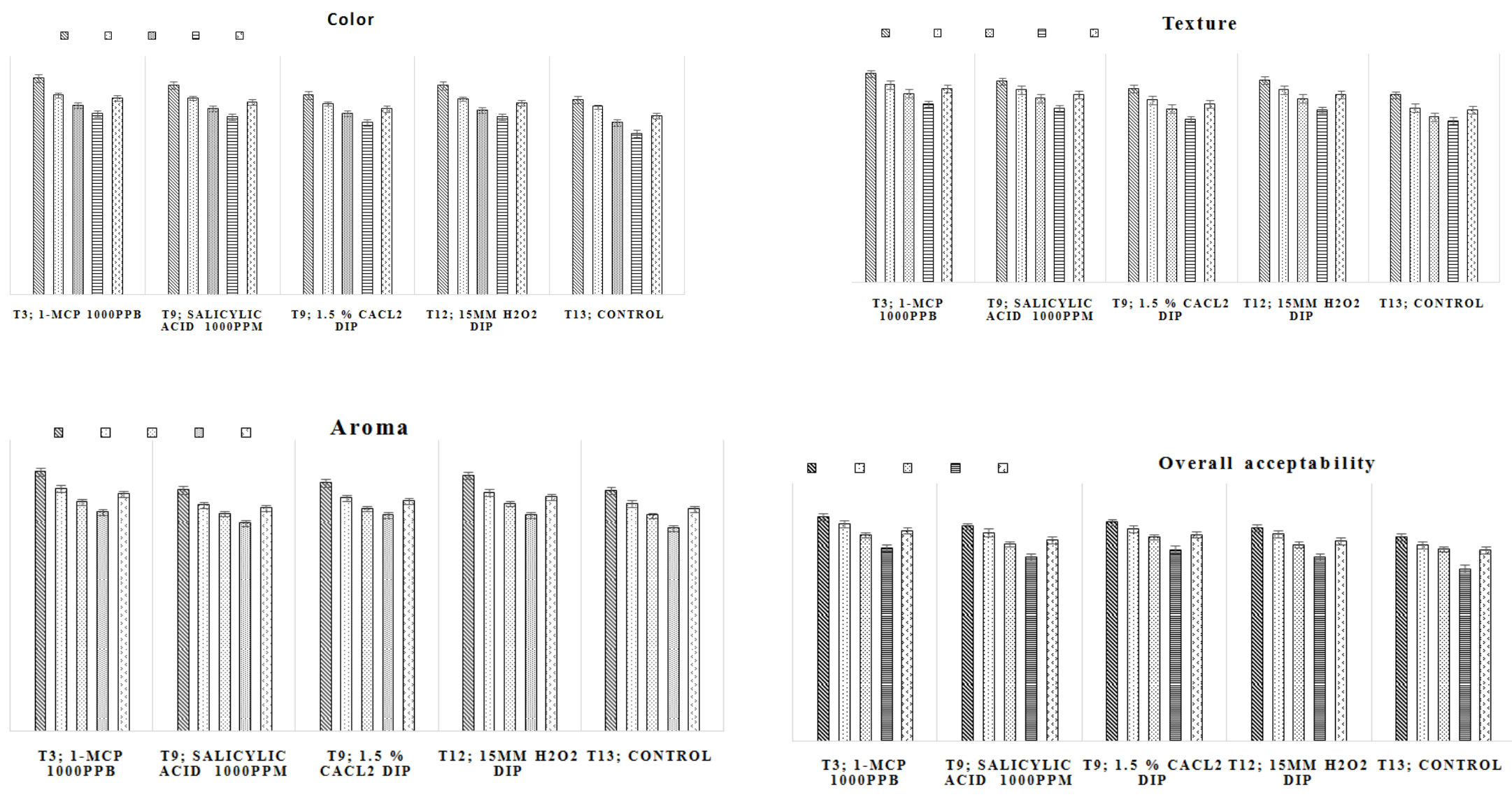
Results indicate a gradual decline in respiration rate of bell pepper fruits under all treatments during storage (Table 4). The lowest mean respiration rate $(17.60 \mathrm{ml}$ $\mathrm{CO}_{2} / \mathrm{kg} / \mathrm{hr}$ ) was observed in response to 1 MCP @ 1000 ppb followed by 1-MCP fumigation@750 ppb (17.63 ml CO $2 / \mathrm{kg} / \mathrm{hr})$, 1-MCP fumigation @ 500 ppb $(17.67 \mathrm{ml}$ $\mathrm{CO}_{2} / \mathrm{kg} / \mathrm{hr}$ ) and salicylic acid $3000 \mathrm{ppm}$ (17.69 $\mathrm{ml} \mathrm{CO} / \mathrm{kg} / \mathrm{hr}$ ), respectively, whereas the control fruits exhibited the highest respiration rate $\left(18.48 \mathrm{ml} \quad \mathrm{CO}_{2} / \mathrm{kg} / \mathrm{hr}\right)$ significantly higher than that recorded in other treatments. Inhibition of ethylene action by 1-MCP during fruit ripening has also been reported in apricot (Fan et al., 2000), peach (Chang et al., 2003; Rasori et al., 2002; Grima et al., 2005) and plum (Khan and Singh, 2008).

Data on color rating of bell pepper fruits, as affected by various postharvest treatments during storage shows that fruits treated with 1-MCP @ 1000 ppb were the most acceptable obtaining a mean score of 7.41 after 28 days of storage at $10 \pm 2^{\circ} \mathrm{C}$, and was the most effective treatment in maintaining color of the fruit (Fig. 1). The findings clearly indicate that the fruit texture was affected significantly by different PHT treatments, during storage to varying extents. It is evident from the data that the average score for texture, as evaluated on a 9 point hedonic scale, decreased throughout storage under all treatments however, fruits treated with 1-MCP @ 1000 ppb exhibited maximum mean texture 7.61 and was followed by 1-MCP fumigation @ $750 \mathrm{ppb}, 1-\mathrm{MCP}$ fumigation @ 500 ppb, salicylic acid @ 3000 ppm and salicylic acid @ 2000 ppm, respectively (Fig. 1) whereas, data on aroma rating of bell pepper fruits, shows that fruits treated with 1-MCP fumigation @ 1000 ppb were the most acceptable obtaining a mean score of 7.34 after 28 days of storage at $10 \pm 2^{\circ} \mathrm{C}$ and hence, it was the most effective treatment in maintaining aroma of the fruit (Fig. 1). The retention of sensory quality of bell pepper fruits with 1-MCP treatments is in accordance with earlier observations for pear (Mahajan et al., 2010), guava (Bassetto et al., 2005), apricots (Fan et al., 2002). Further, the fruits treated with $1000 \mathrm{ppb}$ (8.19), MCP significantly retained highest overall acceptability (8.19) compared to other treatments after 28 days of storage at $10 \pm 2^{\circ} \mathrm{C}$. Findings clearly indicate that potential of different treatments in retaining the storage quality of bell pepper fruits. However, overall $\mathrm{T}_{3}$ treatment i.e. 1-MCP $1000 \mathrm{ppb}$ fumigation for 24 hours was found to be most effective treatment in retaining all the quality parameters up to highest level and was followed by salicylic acid dip for 5 minutes @ 1000 ppm, 10 minute dip in 1.5 per cent calcium chloride and $\mathrm{H}_{2} \mathrm{O}_{2}$ dip for 30 minutes @ $15 \mathrm{mM}$, respectively.

The present investigations suggests that among different postharvest treatments with chemical substances 1-MCP fumigation @ $1000 \mathrm{ppb}$ proved to be most effective treatment in maintaining fruit quality and minimizing deterioration during 28 days storage at $10 \pm 2^{\circ} \mathrm{C}$.

\section{Acknowledgment}

The present study has been carried out in post-harvest physiology laboratory of Deptt. Of Food Science and Technology UHF, Nauni, Solan (H.P.) under supervision of Dr. K. S. Thakur (Professor) during the year 2015 and the financial assistance provided by the institution during the study is fully acknowledged.

\section{References}

Afek. U., Orenstein, J., and Nuriel, E. 1999. Fogging disinfectants inside storage room against pathogens of potatoes and 
sweet potatoes. Crop Protection, 18: 111-114.

Akhtar, A., Abbasi, N.A., and Hussain, A. 2010. Effect of calcium chloride treatments on quality characteristics of loquat fruit during storage. Pak. J. Bot., 2(1): 181-188.

Anthon, E., Lestrange, M., and Barrett, M. 2011. Changes in $\mathrm{pH}$, acids, sugars and other quality parameters during extended vine holding of ripe processing tomatoes. J. Food Sci. Agri., 93: 98-109.

Bassetto, B., Jacomino, A.P., Pinheiro, A.L., and Kluge, R.A. 2005. Delay of ripening of "Red Sato" guava with 1methylcyclopropene. Postharvest Biol. Technol., 35: 303-308.

Bayoumi, Y.A. 2008. Improvement of postharvest keeping quality of white pepper fruits (Capsicum annuum, L.) by hydrogen peroxide treatment under storage conditions. Acta Biol. Szegediensis, 52(1): 7-15.

Behra, T.K., Patil, R.K., Sen, N., and Singh, M. 2004. Effect of maturity at harvest on physicochemical attributes of sweet pepper (Capsicum annuum var. grossum) varieties. Indian J. Agri. Sci., 74: 251-253.

Bray, H.C., and Thorpe, W. 1954. Analysis of phenolic compounds of interest in metabolism. Methods Biochem. Analysis, 1: 27-52.

Chang, J., Zhang, P., Wang, L. and Tian, L. 2003. Effect of 1- methylcyclopropene (1-MCP) on several physiological indices of peach during postharvest cold storage. Plant Physiol. Communications, 39(6): 613-615.

Chen Wen Xuan, Gao Hai Yan, Zhou Yong Jun, Zhu Meng Yi and Mao Jin Ling. 2005. Study on safety storage techniques of juicy peach. J. Yunnan Agri. Univ., 20(3): 443-445.

Cheng, S., Wei, B., and Shujuan, J. 2012. A novel 1-methylcyclopropene treatment for quality control in 'Nangou' pears at ambient temperature. African J. Agri. Res., 7(14): 2236-2242.

Cuquel, F.L., Fantin, E.R., Monte, B., Motta, A.C., Mio, LLM de., and Monteiro, L.B. 2006. Effect of 1-MCP on postharvest performance of 'Chimarrita' peach fruits. ActaHorticulturae, 7(13): 497-499.

Fan, X., Argenta, L., and Mattheis, J.P. 2002. Interactive effects of 1-MCP and temperature on 'Elberta' peach quality. Horticulture Sci., 37(1): 134-138.

Farag, K.M., Haikal, A.M., and Attia, S.M. 2012. Effect of some preharvest treatments on quality and ripening of "Canino" apricot fruits: Applications at pit hardening. Australian J. Basic and Appl. Sci., 6(7): 518- 531.

Grima, C.D., Pena, A.R., and Vendrell, M. 2005. Effect of different gas treatments (1-MCP and N2O) and MA on ethylene biosynthesis, ripening and quality of peaches. Acta Horticulturae, 682(2): 973-978.

Isaac, O. and Maalekuu, B.K. 2013. Effect of some postharvest treatments on the quality and shelf life of three cultivars of carrot (Daucus carota L.) during storage at room temperature. American J. Food and Nutri., 3(2): 64-72.

Jiang, Y., Joyce, D.C. and Terry, L.A. 2001. 1-Methylcyclopropene treatment affects strawberry fruit decay. Postharvest Biol. Technol., 23: 227-232.

Khan, A.S, and Singh, Z. 2008. 1methylcyclopropene application and modified atmosphere packaging affect ethylene biosynthesis, fruit softening, and quality of 'Tegan Blue' Japanese plum during cold Storage. J. Americian Society for Horticultural Sci., 133: 290299.

Lane, J.H and Eynon, L. 1923. Determination of reducing sugar by Fehling's solutions 
with methylene blue as indicator. $J$. Society of Chem. Industry, 42: 32.

Mahajan, B.V.C., Singh, K. and Dhillon, W.S. 2010. Effect of 1methylcyclopropane (1-MCP) on storage life and quality of pear fruits. $J$. Food Sci. Technol., 47(3): 351354.

Mapson, L.W. 1970. Vitamins in fruits. In: Hulme AC (ed.), The Biochemistry of Fruits and Their Products, vol. 1. Academic Press, London. pp. 369-383.

Marpudi, S.L, Abirami, L.S.S., Pushkala, R, and Srividya, N. 2011. Enhancement of storage life and quality maintenance of papaya fruits using Aloe vera based anti-microbial coating. Indian $J$. Biotechnol., 83: 89.

Mateljan, G. 2007. The World's Healthiest Foods: Essential guide for the healthiest way of eating. http://www.whfoods.com.

NHB. 2014. Annual production of vegetables. National Horticulture Board, Gurgaon, Haryana

Ochie, C.O., Barionny, F.M. and Woods, F.M. 1993. Calcium mediated postharvest changes in storability and fruit quality of peaches. Proceedings of the Florida State Horticultural Society, 106: 266-269.

Park, S.M, Kang, W.H, Kim, I.S. and Jeong, C.S. 2001. Effect of storage temperature and relative humidity on the quality of red hot pepper and sweet pepper. $J$. Horticultural Sci. Korean Soc., 42: 519522.

Ranganna, S. 1986. Handbook of Analysis and Quality Control of Fruit and Vegetable Products. 2nd ed. Tata McGraw Hill Publication Company, New Delhi.

Rasori, A., Ruperti, B., Bonghi, C., Tonutti, P., and Ramina, A. 2002. Characterization of two putative ethylene receptor genes expressed during peach fruit development and abscission. J. Experimental Bot., 53: 2333-2339.

Robards, K., Penzle, P.D., Tucker, G., Swatsitang, P., and Solver, W. 1999. Phenolic compounds and their role in oxidative processes in fruits. Food Chem., 66(4): 401-436.

Ruoyi, K., Zhifang, Y., and Zhaoxin, L.Z. 2005. Effect of coating and intermittent warming on enzymes, soluble pectic substances and ascorbic acid of Prunus persica cv. 'Zhonghuashoutao' during refrigerated storage. Food Res. Int., 38: 331-336.

Sadasivam, S., and Manickam, A. 1978. Phenolics. In: Biochemical Methods. 2nd Edition. New Delhi: New Age International (O) Ltd. p. 193-194.

Saftner, R.A., Bai, J., Abbott, J.A., and Lee, Y.S. 2003. Sanitary dips with calcium propionate, calcium chloride, or calcium amino acid chelates maintain quality and shelf stability of fresh-cut honeydew chunks. Postharvest Biol. Technol., 29: 257-69.

Salvador, A., Cuquerella, J., and Javega, J.M. 2003. 1-MCP treatment prolongs postharvest life of 'Santa Rosa' plums. J. Food Sci. Technol., 68(4): 15041510.

Sapers, G.M., Miler, R.L., Pilizota, V., and Mattrazzo, A.M. 2001. Antimicrobial treatments for minimally processed cantaloupe melon. J. Food Sci., 66: 345349.

Schaik, A., Van, S., and Slaats, W.J. 1992. Semperfresh prolongs storage life of apples. Fruitteelt, 80(48): 18-19.

Singh, D.P., Anand, N., and Deshpande, A.A. 1993. Improvement of bell pepper. In: KL Chadha and G Kalloo (eds.), Advances in Horticulture. New Delhi: MPH, Vol.5. pp. 87-104.

Sisler, E.C., and Serek, M. 1997. Inhibition of ethylene responses in plants at the receptor level: recent developments. 
Physiologia Plantarum, 100: 577-582.

Tandon, M.P and Tandon, R.N. 1974. Post infection changes in ascorbic acid contents of aonla fruits caused by Aspergillusniger. Curr. Sci., 43(7): 218219.

Taneja, S., Parmar, M.S.S., Williamson, S., and Jain, D. 1983. Changes in ascorbic acid contents of aonla fruit (EmblicaofficinalisGaertn.) after fungal infection. Sci. Culture, 48: 225-226

Tareen, M.J., Abbasi, N.A., and Hafiz, I.A. 2012. Effect of salicylic acid treatments on storage life of peach fruits $\mathrm{cv}$. 'Florda King'. Pak. J. Bot., 44(1): 119124.

Tian, M.S., Prakash, S., Elgar, H.J., Young, H., Burmeister, D.M., and Ross, G.S. 2000. Responses of strawberry fruit to 1-methylcyclopropene (1-MCP) and ethylene. Plant Growth Regulation, 32: 83-90.

Topuz, A., and Ozdemir, F. 2004. Influence of gamma radiation and storage on the capsaicinoids of sun-dried and dehydrated paprika. Food Chem., 86: 509-515.

Wang, L., and Shaohua, Li. 2008. Role of salicylic acid in postharvest physiology. In: Fresh Produce. Global science, UK. pp. 1-5.

Wilkinson, B.G. 1965. Some effects of storage under different conditions of humidity on the physical properties of apple. J. Horticultural Sci., 40: 58-65.

Yamaguchi, T., Katsuda, M., Oda, Y., Terao, J., Kanazawa, K., and Oshima, S. 2003. Influence of polyphenoloxidase and ascorbate oxidase during cooking process on the free radical scavenging activity of vegetables. Food Sci. Technol. Res., 9(1): 79-83.

Yeganeh, M.A., Hadavi, E., and Kalhori, M. 2013. Effects of salicylic acid on quality of 'BidanehSefid' table grapes during cold storage. Int. J. Agri. Crop Sci., 5(18): 2041-2047.

\section{How to cite this article:}

Thakur, K.S., Kiran Jyoti, Satish Kumar and Sunakshi Gautum. 2017. Improvement of Postharvest Keeping Quality of Bell Pepper (Capsicum annum L.) Fruits Treated with Different Chemicals following Cold Storage. Int.J.Curr.Microbiol.App.Sci. 6(7): 2462-2475. doi: https://doi.org/10.20546/ijcmas.2017.607.291 